\title{
The Edwin Ford Piper Collection of Folksongs
}

\author{
HA R RY OSTER
}

Among the significant and fascinating manuscripts in our library is the folksong collection of Edwin Ford Piper (1871-1939), a Nebraskan who taught in the Department of English at the University of Iowa from 1905 until his death.

As a boy in Auburn, Nebraska, Piper turned an eager ear toward the folksongs of hired men, cowboys, tramps slurping their mulligan stews from tin cans simmering over camp-fires, wandering musicians plunking their way with more gusto than profit through country fairs, horse races, and other local festivities. He also learned songs from more genteel sources: Lucinda, his mother; Ella, his sister; and the various performers, accompanying themselves on fiddle, banjo, or accordion, who entertained at meetings of the country literary society. Like many collectors, Piper started out casually, memorizing the tunes and texts he enjoyed singing to entertain his friends.

In 1897, however, he began to copy down old songs which were then primarily in oral circulation. He also gathered the song texts printed in farm journals and newspapers. Around 1909, Piper became more systematic and comprehensive in his collecting. He wrote down the songs he himself remembered from his boyhood, transcribed texts from the lips of ballad singers, wrote to the contributors of songs to newspapers and assembled songs from them, swapped songs with friends from other communities, collected from the scrapbooks and memory books of old people. His most active period of collecting ended with World War I. After the war, he pursued songs only occasionally.

By the time of his death in 1939, he had preserved 828 folksongs as well as hundreds of riddles, rhymes, play-party games, folk sayings, and quadrille calls. Also here among his papers is a scrapbook in which are mounted 150 nineteenth-century broadsides, purchased in 1914 from a 
bookseller in Manchester, England, an important collection worthy of extended study.

The songs, the principal focus of this article, are mostly from Iowa and Nebraska, but there are also songs from Texas, Colorado, Oklahoma, the Dakotas, Illinois, Pennsylvania, New York, Tennessee, Arkansas, and other states. As is true of the bulk of any American regional collection, most of the songs are typical of a broad geographic area and a substantial number are variants of lyrics and ballads from the British Isles.

Diverse and extensive as Piper's collection is, in an article of this brevity one can mention only a few songs and indicate their general type. Among the most colorful are those which were used to accompany folk dancing in the old west. Dancing to the fiddle was both a favorite frontier activity and also the bane of some religious sects, who saw the fiddle as the devil's instrument, a fiendish device for luring the unwary down the primrose path. Forbidden to dance by their elders, young adults devised the play-party, which was in theory a game, but in fact a dance in which the music was supplied by the singing and hand-clapping of the participants. The disguise is quite transparent in "Baptist Game," a playparty song which Piper learned from his mother, Lucinda, in Nemaha County, Nebraska, in 1880. The sentiment is clearly hedonistic.

Come all who are young and wild in your ways

Come sow your wild oats in your youthful days.

Then give me your arm and we'll joggle along, Joggle along, joggle along.

Then give me your arm and we'll joggle along That you may be happy to see your grandpappy When you grow old;

That you may be happy to see your grandpappy When you grow old.

North Carolina Folksongs lists two variants of the song under the title "Wild Oats."

A. from Gertrude Allen Taylorsville, Alexander County:

Turn young men from your evil ways;

Go sow your wild oats in the early days-

That you may be happy when you grow old.

B. from Ethel Brown, Catawba County:

Turn ye, young men, from your evil ways;

Don't sow wild oats in your early days-

That you may be happy when you grow old.

With only slight variation in phrasing these two variants offer opposite advice for reaching a contented old age, the first by having led a life full of pleasure, the second by having led a life full of virtue. 
From Connecticut comes another variant under the title "Old Maids." This is accompanied by instructions for playing the game which can be applied also to Piper's variant:

All ye that are single and wild in your ways, Come sow your wild oats in your youthful days, And you shall live happy, you shall live happy

When you grow old.

The day is far spent and the night's coming on, So give us your arm and go joggling along, And you shall be happy, you shall be happy

When you grow old.

These are the instructions to the players:

At the words, "So give us your arm," the couples which are marching change off, and each girl tries to get a boy's arm, and escape being left over for the old maid, the number of players being so arranged that the girls make one more than the young men.

Also well represented in the Piper collection is a class of sentimental ballads of a popular well-defined type-the emigrant's nostalgic lament for the old country. Some of the examples are "The Miner's Dream of Home" (English), "The Emigrant's Farewell" (Irish), and three variants of "My Little German Home Across the Sea." Interestingly there seems to be no record of this song in German, and the tune is identical to that of the grimly comic pioneers' complaint, "My Little Old Sod Shanty on the Claim." Piper's version was sung by a Mrs. U. B. Rogers (no date or place listed):

My Little German Home Across the Sea

I love to think about the days so full of glee and joy,

That never will come back again to me.

$\mathrm{Oh}$, it was many years ago, when but a little boy,

That I lived there so happy, light and free.

I used to play about all day and drive the cows and sheep,

Until I was as tired as I could be,

And when my evening prayer was said, I'd lay me down to sleep,

In that little German home across the sea.

Chorus:

No matter where I roam, I don't forget my home,

That home, it was so ever dear to me,

And when my evening prayer was said,

I'd lay me down to sleep

In that little German home across the sea.

I never shall forget the day I left the Fatherland,

To sail across the stormy ocean foam. 
My friends, they came around me and took me by the hand, And hoped that safely back again I'd come.

My father and my mother, old, they both stood by the door, And gave their tearful blessings unto me,

But now, they both are dead and gone

I ne'er shall see them more,

In that little German home across the sea.

Chorus:

I've traveled many weary miles around this world for years,

And many more, I yet expect to roam,

But when I lay me down to sleep, then in my dreams appears,

A vision of that dear old German home,

And when my days are over here, if it were for the best,

Oh, it would bring much joy and peace to me,

If I could close my eyelids here, and lay down to sleep,

In that little German home across the sea.

In South Omaha (no singer is listed) Piper collected a brief but intriguing fragment, "Ole Bull and Dan Tucker," one of the innumerable variants of "Old Dan Tucker," the minstrel show song composed by Daniel Decatur Emmett (1818-1904), probably drawing on folk Negro sources. The song in the Piper collection runs:

Ole Bull tuned up his fiddle,

Squeezed the neck and then the middle;

Play Niagara, rapids and all,

Till he sweat like that same waterfall.

But old Niagara was no use

When Tucker up the banjo screws,

For he made a hurricane to rise

Till roofs and trees flew through the skies.

Ole Bull (1810-1880) was a colorful Norwegian virtuoso violinist of international fame who toured the United States with sensational success five times between 1843 and 1879. Using a bow of unusual length and weight to suit his powerful physique, Ole Bull was noted for playing up a storm. In the two stanzas we have from Piper (neither of which duplicates any of the six Emmett first published), the contest between Ole Bull and Dan Tucker takes on the titanic proportions of American frontier epic in the lively imaginative tradition of the tall tale.

"My Name Is Edward Broderick" (perhaps collected from Broderick himself, though we have no information among Piper's manuscripts) is in the ancient tradition of songs performed by blind street-singers describing their personal tragedy in order to beg charity from passers-by. 
I was born in Illinois,

My parents came to Iowa when I was but a boy.

I remember well the happy days, the joy that filled my mind,

As I viewed the fields and flowers gay, but now, alas! I'm blind.

A boiler maker I'm by trade, I live in east Des Moines;

I worked four years in MacDonald's shop, not only for myself,

But for my parents, they were poor, needed all my help.

I earned my bread it tasted sweet, I was full of life.

I little knew my sunny days would all be changed to night,

But God he knows what is the best, we'll know it by and by,

A hot iron chip, a hot iron chip struck me in my right eye.

It grieved me much to lose its sight, it caused me weeks of pain;

I prayed to God I'd one bright eye, I went to work again.

Two months had scarcely passed and gone, when working in my speed,

A hot iron splint hit my left eye and I was blind indeed.

My mother wept from day to day, she does not seem the same, She said, "Dear son, what will you do, you ne'er can see again."

Said I, "Dear mother, do not weep, God our laws has made;

There's a home for poor blind boys like me, I'll go learn a trade."

Three years I spent in Vinton, in that dear home,

I learned the trade of making brooms, but money I have none;

If some kind friends will pity me and give me a little help,

I'll buy some stock and start a shop, I'll support myself.

And I'll know the Lord He will reward more than a thousand fold,

I hope He'll leave with you bright eyes that can't be bought with gold;

I hope someday we'll meet again, by other glorious plan,

Where the poor are rich, and blind can see up in that heavenly land.

In addition to the Child ballads, songs derived from broadsides, playparty songs, sentimental parlor ballads, street-singing beggars' laments, expressions of emigrants' nostalgia, songs satirizing men and women in public life and poking fun at changing times and fashions, there are many other categories, the most important of which we shall mention.

Religion is generally treated with reverence, as reflected by the many songs pointing a moral, by spirituals and camp-meeting songs, but there is an occasional irreverence, for example, a parody of "Nearer My God to Thee”-" Nero My Dog Has Fleas.” There are some thirty temperance songs which circulated before 1900 , usually advocating local or national prohibition, typified by “The Drunkard's Dream," “I Have Drank My Last Glass," "The Lips That Touch Liquor Shall Never Touch Mine," "Have Courage My Boy to Say No." This point of view is countered by 
drinking songs, one of them a parody, "Another Little Drink," which praises the laying hen and the obliging bartender.

Love lyrics are of course abundantly in evidence, some of them rich in poetic evocative sentiments, one of the most intriguing of which is the romantic tribute in "Kentucky," in which the singer rhapsodizes, "A girl I once knew had the sunshine of good whiskey in her face and form." In addition there are many comic treatments of the battle of the sexes, typified by "Mr. and Mrs. Grumble," in which a farmer insists that he can do more work in one day than she can do in three. When they trade work, by the end of the day he is compelled to admit that she can do more work in one day than he in seven.

The law-abiding citizen's repressed impulse to commit violence finds vicarious expression in outlaw ballads like "Brennen on the Moor" and "Captain Old Blue." With the frontier in the relatively recent historical past in the Middle West, there are, as one might expect, numerous songs connected with it, cowboy songs, for example, expressing the disillusionment of pioneers who went West expecting wealth but finding none. Pride of country is lauded in some songs, but there is also a large group of I.W.W. numbers directing biting satire and hostility against the established order-"Internationale," "Red Flag," and "The White Slave." In addition, there are a few manuscripts not in English-Danish, "Himmeldreisen," "Farvel til Denmark," and "Young People Who Felt the Hard Blow of Fate"; in German, "In dem Schönen Land Chineschen"; in French, "The Canadian Canoe Song"; in Swedish, variants in translation of "The Chicago Fire" and "The Dying Cowboy."

When Edwin Ford Piper died in 1939 only a handful of his songs had been published, some in articles by him in folklore journals, a few others in Carl Sandburg's American Songbag and in the works of Louise Pound. Still to be edited and published is the richly varied folksong collection in the Library of the University of Iowa. 